\section{High Tunnel and Outdoor Production of Containerized Annual Bedding Plants in the Midwestern United States}

\author{
Madeline W. Olberg and Roberto G. Lopez ${ }^{1,2}$
}

ADDITIONAL INDEX wORDs. daily light integral, cold-tolerant crops, hoop house, mean daily temperature

Summary. Due to the high cost associated with constructing and operating a greenhouse, many growers have begun using alternative, low-input methods for bedding plant production, such as unheated high tunnel and outdoor production. Previous research indicates that bedding plant production in unheated high tunnels may be suitable for cold-tolerant species, but flowering is delayed compared with greenhouse production. To our knowledge, there has been no published research on the effects of outdoor production on bedding plant species. The objectives of this study were therefore to 1 ) compare the growth and development of 10 cold-tolerant and intermediate annual bedding plant species grown in an unheated high tunnel or in an unprotected outdoor growing area, 2) evaluate the effect of a 1-week acclimation period in the high tunnel before outdoor production, and 3) quantify the effectiveness of these production methods for producing high-quality bedding crops. Seedlings of 'Antigua Orange' african marigold (Tagetes erecta), 'Hot Cakes White' stock (Matthiola incana), and 'Lilac Flame' primula (Primula acaulis), and rooted cuttings of 'Aloha Kona Hot Pink' calibrachoa (Calibrachoa $\times$ bybrida), 'Royal Lavender' regal geranium (Pelargonium $\times$ domesticum), 'Bella Oceano' lobelia (Lobelia erinus), 'Potunia Plus Red' petunia (Petunia $\times$ bybrida), 'Phloxy Lady Purple' phlox (Phlox maculata), 'Summertime Pink Charme' osteospermum (Osteospermum ecklonis), and 'Empress Purple' verbena (Verbena $\times$ bybrida) were transplanted on 13 Apr. 2015 (week 16) into an unheated high tunnel or an outdoor growing area, or into an unheated high tunnel for a 1 -week acclimation period before being moved outdoors. Average mean daily air temperature was $2.3{ }^{\circ} \mathrm{C}$ lower outdoors compared with inside the high tunnel, whereas average daily light integral (DLI) increased by $11.7 \mathrm{~mol} \cdot \mathrm{m}^{-2} \cdot \mathrm{d}^{-1}$. All plants were delayed when grown outdoors compared with in the high tunnel, and all marigolds grown outdoors died in April when outdoor air temperatures dropped below $-4{ }^{\circ} \mathrm{C}$. When plants were acclimated for a 1 -week period before outdoor production, all species, with the exception of regal geranium, were delayed by less than 1 week compared with those grown in the high tunnel. Stem length of all species grown outdoors was reduced or similar to those in the high tunnel, whereas biomass accumulation and branch number was unaffected or increased for most species. Overall, high-quality bedding plants could be grown outdoors, although development may be delayed compared with high tunnel production. Growers must be aware of the risk of crop loss due to extreme temperatures and plan for delays when growing annual bedding plant crops outdoors.

$\mathrm{T}$ ypical annual bedding plant production in northern latitudes $\left(\geq 40^{\circ} \mathrm{N}\right)$ occurs from midwinter to spring in heated greenhouses. Unfortunately, greenhouse heating can account for $10 \%$ to

Department of Horticulture and Landscape Architecture, Purdue University, 625 Agriculture Mall Drive West Lafayette, IN 47907

We gratefully acknowledge Lopez lab members and Judy Santini for research and statistical assistance; Everris NA, Inc. for fertilizer; Ball Horticultural Company and Dümmen-Orange for plant material; and SunGro Horticulture for media.

${ }^{1}$ Current address: Department of Horticulture, Michigan State University, 1066 Bogue Street, East Lansing, MI 48824.

${ }^{2}$ Corresponding author. E-mail: rglopez@msu.edu.

doi: 10.21273/HORTTECH03454-16
$30 \%$ of operating costs for these greenhouse operations (Lopez and Runkle, 2014). The high cost and duction has therefore given way to the consideration and implementation of alternative, low-cost production input required for greenhouse pro- methods. One alternative is growing or finishing annual bedding plants in an unheated high tunnel. High tunnels consist of a frame, generally made of pipes or galvanized tubing, covered by a single or double layer of polyethylene (Lamont, 2009). High tunnels typically do not have any type of automated heating, cooling, or ventilation system, and thus are passively solar heated and cooled via sidewall, endwall, and/or gable vents (Lamont, 2009). Previous research at Purdue University and Cornell University has shown that unheated high tunnel production is a plausible method for some coldtolerant bedding crops, but development is often delayed (Currey et al., 2014; Gerovac et al., 2015).

Rate of plant development is zero at or below the species-specific base temperature $\left(T_{\mathrm{b}}\right)$, increases linearly up the optimum temperature $\left(T_{\text {opt }}\right)$, after which it rapidly decreases and ceases upon reaching the maximum temperature $\left(T_{\max }\right)$ (Blanchard and Runkle, 2011). Plants can be categorized by their $T_{\mathrm{b}}$, such that when $T_{\mathrm{b}} \leq 4^{\circ} \mathrm{C}$, $4{ }^{\circ} \mathrm{C}<T_{\mathrm{b}}<7{ }^{\circ} \mathrm{C}$, or $T_{\mathrm{b}} \geq 7^{\circ} \mathrm{C}$, plants are categorized as cold-tolerant, coldintermediate, or cold-sensitive, respectively (Blanchard and Runkle, 2011). The lack of active heating in high tunnels results in a decreased mean daily temperature (MDT) compared with greenhouse production in northern latitudes during the traditional bedding plant season. For example, average MDT has been reported to be 6.3 to $7.5^{\circ} \mathrm{C}$ and 1.4 to $3.6^{\circ} \mathrm{C}$ colder, in April and May, respectively, in a high tunnel compared with in a greenhouse with an MDT set point of 18 to $21^{\circ} \mathrm{C}$ in Tippecanoe, IN (Currey et al., 2014; Gerovac et al., 2015). Consequently, time to flower (TTF) of 'Telstar Crimson' dianthus (Dianthus chinensis), 'Wave Pink' petunia, and 'Liberty Classic Yellow' snapdragon (Antirrbinum majus) transplanted during week 13 were delayed by 8,8 , and $26 \mathrm{~d}$,

\begin{tabular}{llll}
\hline $\begin{array}{l}\text { Units } \\
\begin{array}{l}\text { To convert U.S. to SI, } \\
\text { multiply by }\end{array}\end{array}$ & U.S. unit & SI unit & $\begin{array}{l}\text { To convert SI to U.S., } \\
\text { multiply by }\end{array}$ \\
\hline 29.5735 & $\mathrm{fl} \mathrm{oz}$ & $\mathrm{mL}$ & 0.0338 \\
0.3048 & $\mathrm{ft}$ & $\mathrm{m}$ & 3.2808 \\
2.54 & inch $(\mathrm{es})$ & $\mathrm{cm}$ & 0.3937 \\
28.3495 & $\mathrm{oz}$ & $\mathrm{g}$ & 0.0353 \\
1 & $\mathrm{ppm}$ & $\mathrm{mg} \cdot \mathrm{L}^{-1}$ & 1 \\
0.001 & $\mathrm{ppm}$ & $\mathrm{mL} \cdot \mathrm{L}^{-1}$ & 1,000 \\
$\left({ }^{\circ} \mathrm{F}-32\right) \div 1.8$ & ${ }^{\circ} \mathrm{F}$ & ${ }^{\circ} \mathrm{C}$ & $\left({ }^{\circ} \mathrm{C} \times 1.8\right)+32$
\end{tabular}


respectively, when grown in an unheated high tunnel compared with a heated greenhouse; although, at later planting dates, this delay was minimal or nonexistent (Gerovac et al., 2015). Currey et al. (2014) also found that 'Dreams Midnight' petunia, 'Super Parfait Raspberry' dianthus, and 'Penny Lane Mix' viola (Viola $\times$ cornuta), planted during week 14, experienced no delay in development when grown in an unheated high tunnel compared with a heated greenhouse.

As greenhouse space becomes limited in the spring, some growers in northern latitudes begin growing outdoors (Crum, 2008; M.W. Olberg, personal observation). However, the morphological and developmental effects of unprotected outdoor bedding plant production are not well documented. MDT is often lower in outdoor production than in high tunnels during the traditional bedding plant production period, and therefore, further developmental delays could be expected (Wien, 2009). Developmental delays in greenhouse production are extremely undesirable due to the high costs of production per square foot, but crop delays, if planned for, are not as deleterious in low-cost production systems, such as high tunnel or outdoor production. Additionally, the DLI can be significantly higher in high tunnels compared with greenhouses and would be even higher outdoors (Currey et al., 2014; Gerovac et al., 2015). High DLIs have been reported to hasten flowering and improve overall crop quality, in terms of increased biomass accumulation, increased branching, more compact growth, and increased number of visible buds (Adams et al., 1998; Blanchard et al., 201la, $201 \mathrm{lb}$; Faust et al., 2005; Heins et al., 2000; Kaczperski et al., 1991; Oh et al., 2010). The production of more compact plants due to high DLI and increased air movement in outdoor production could also limit the need for chemical plant growth regulator (PGR) applications (Crum, 2008; Faust et al., 2005; Latimer, 1998; Liu and Heins, 2002; Moccaldi and Runkle, 2007). These benefits could consequently make high tunnel or outdoor production systems suitable for cold-tolerant and cold-intermediate bedding plant crops, although the risks of crop loss due to weather extremes must also be considered. High tunnel or outdoor production may also benefit the ultimate consumer, as plants become acclimated to outdoor conditions during production, before transplant into the landscape.

Although there is published information on the growth and development of various bedding plant species in unheated high tunnels, to our knowledge, there is no published information on the effects of unprotected outdoor production on cold-tolerant and cold-intermediate bedding plants, especially in northern latitudes. Therefore, the objectives of this study were to l) compare the growth and development of 10 annual bedding crop species grown in an unheated high tunnel or outdoors, 2 ) evaluate the effect of a l-week initial acclimation period in the high tunnel before outdoor production, and 3) quantify the effectiveness of these production methods for producing high-quality bedding crops. This information could be valuable for growers to determine what crops can be produced outdoors and what they can expect in terms of crop timing, morphology, and freezing injury, and for exemplifying any effects of an acclimation period before outdoor production.

\section{Materials and methods}

Plant material and culture. Between weeks 12 and 13 (19 Mar. to 25 Mar. 2015), seedlings of 'Antigua Orange' african marigold, 'Hot Cakes White' stock, and 'Lilac Flame' primula in 288 -cell $(6-\mathrm{mL}$ individual cell volume) plug trays were received at Purdue University, West Lafayette, IN [Purdue (lat. $\left.40^{\circ} \mathrm{N}\right)$ ]. During week 15 (8 Apr. 2015), rooted cuttings of 'Aloha Kona Hot Pink' calibrachoa, 'Royal Lavender' regal geranium, 'Bella Oceano' lobelia, 'Potunia Plus Red' petunia, 'Phloxy Lady Purple' phlox, 'Summertime Pink Charme' osteospermum, and 'Empress Purple' verbena in 5l-cell (27.2-mL individual cell vol.) liners were received at Purdue. Plants were held until week 16 (13 Apr. 2015) in a glass-glazed greenhouse at an MDT (mean $\pm \mathrm{SD}$ ) of $15.7 \pm 3.1^{\circ} \mathrm{C}$ and an average DLI of $11.8 \pm 3.5 \mathrm{~mol} \cdot \mathrm{m}^{-2} \cdot \mathrm{d}^{-1}$. All plants were irrigated as necessary with clear water, supplemented with
93\% sulfuric acid (Brenntag, Reading, $\mathrm{PA}$ ) at $0.08 \mathrm{~mL} \cdot \mathrm{L}^{-1}$ to reduce alkalinity to $100 \mathrm{mg} \cdot \mathrm{L}^{-1}$ and maintain a $\mathrm{pH}$ within the range of 5.8 to 6.2. Before transplant, plants were fertigated twice per week with clear acidified water supplemented with two water-soluble fertilizers $[3: 1$ mixture of $15 \mathrm{~N}-2.2 \mathrm{P}-12.5 \mathrm{~K}$ and $21 \mathrm{~N}-2.2 \mathrm{P}-16.6 \mathrm{~K}$, respectively (Everris NA, Dublin, $\mathrm{OH}$ )] to provide (in $\mathrm{mg} \cdot \mathrm{L}^{-1}$ ): 200 nitrogen $(\mathrm{N}), 26$ phosphorus $(\mathrm{P}), 163$ potassium $(\mathrm{K})$, 50 calcium $(\mathrm{Ca}), 20$ magnesium $(\mathrm{Mg})$, 1.0 iron $(\mathrm{Fe}), 0.5$ manganese $(\mathrm{Mn}), 0.5$ zinc $(\mathrm{Zn}), 0.24$ copper $(\mathrm{Cu}), 0.24$ boron (B), and 0.1 molybdenum (Mo).

All plants were transplanted on 13 Apr. 2015 (week 16) into 4.5-inch $(600 \mathrm{~mL})$ containers filled with soilless substrate consisting of (by vol.) $65 \%$ peat, $20 \%$ perlite, and $15 \%$ vermiculite (Fafard 2 Mix; SunGro Horticulture, Agawam, MA). Thirty-two randomly selected plants of each species were moved into an east-westoriented high tunnel, and 16 randomly selected plants of each species were moved to an unprotected outdoor growing area. All containerized plants were placed into trays on top of a single layer of commercial grade landscape fabric outdoors and in the high tunnel. After a l-week acclimation period in the high tunnel, 16 plants of each species were moved from the high tunnel to the outdoor growing area.

All plants were overhead handirrigated as necessary with clear water, supplemented with $93 \%$ sulfuric acid (Mallinckrodt Chemicals, St. Louis, $\mathrm{MO}$ ), to reduce alkalinity to $\approx 100$ $\mathrm{mg} \cdot \mathrm{L}^{-1}$ calcium carbonate $\left(\mathrm{CaCO}_{3}\right)$, and $21 \mathrm{~N}-2.2 \mathrm{P}-16.6 \mathrm{~K}$ water-soluble fertilizer (Peters Excel 21-5-20, Everris $\mathrm{NA}$ ) to provide (in $\mathrm{mg} \cdot \mathrm{L}^{-1}$ ): $200 \mathrm{~N}, 26$ $\mathrm{P}, 163 \mathrm{~K}, 1.0 \mathrm{Fe}, 0.5 \mathrm{Mn}, 0.5 \mathrm{Zn}, 0.24$ $\mathrm{Cu}, 0.24 \mathrm{~B}$, and 0.1 Mo. After rain events, plants in the high tunnel were irrigated with clear acidified water to imitate similar saturation and leaching.

High TUNNEL AND OUTDOOR GROWING AREA ENVIRONMENT. High tunnel and outdoor environments were located at the Meigs Farm, Throckmorton Purdue Agriculture Center, Tippecanoe, IN (lat. $40.29^{\circ} \mathrm{N}$, long. $86.88^{\circ} \mathrm{W}$ ). A single layer of clear greenhouse-grade 6-mil polyethylene covered the $24 \times 48$-ft high tunnel structure (Snow Arch; Atlas Manufacturing, Alapaha, GA). Ventilation was automated using a motorized crank 
system (E-Z Roll-Up Motorized Crank System, Atlas Manufacturing) with an electronic controller (24-V Natural Ventilation Controller, Atlas Manufacturing) powered by two electric solar panels to roll up the sidewalls. Sidewalls were set to open to $1 \mathrm{~m}$ height when air temperature inside the high tunnel reached $29^{\circ} \mathrm{C}$ and close when inside air temperature dropped below $17^{\circ} \mathrm{C}$. Gable vents were set to open at $25^{\circ} \mathrm{C}$ using a heat-activated louver opener (Atlas Manufacturing). On nights when outdoors forecast temperature lows were predicted to be $<1{ }^{\circ} \mathrm{C}$ or $<3{ }^{\circ} \mathrm{C}$, rowcover $\left(+\mathrm{AG}^{-}\right.$ 19; Agribon, San Luis Potosi, Mexico) was pulled over all plants or just outdoor plants, respectively.

E N VIRONMENTAL DATA COLLECTION. Air temperature at plant canopy level was measured every $20 \mathrm{~s}$ using an enclosed thermocouple, and averages were calculated and recorded every $15 \mathrm{~min}$ by a data logger (model 2475 Plant Growth Station; Spectrum Technologies, Plainfield, IL). Substrate temperature and photosynthetic photon flux $(P P F)$ were measured every $30 \mathrm{~s}$ using resistance-based temperature sensors (External Temperature Sensor; Spectrum Technologies) inserted horizontally in the media and quantum sensors (model SQ212; Apogee Instruments, Logan, UT) placed at plant height, respectively. Substrate temperature and DLI averages were recorded every $15 \mathrm{~min}$ by a data logger (WatchDog 2800 Weather Station; Spectrum Technologies). Mean DLI and average, minimum, and maximum media and air temperatures were calculated for each month for each growing environment (Table 1 ).

Data COLLECTION AND CALCUlations. Plants were monitored daily and date of first open flower was recorded for marigold, primula, regal geranium, osteospermum, and verbena when the first flower was fully reflexed. Date marketable was recorded for calibrachoa, regal geranium, lobelia, phlox, and petunia, due to premature flowering. Plants were considered marketable when plants had at least one open flower and filled out the container, completely covering all exposed media. TTF and time to marketable (TTM) were calculated as the number of days from transplant date (13 Apr.) to date of flowering or marketability, respectively. Stem length was measured for all species from the base of the plant to the apical meristem. Plant width and perpendicular width were also measured for all species, and growth index (GI) was calculated $[\mathrm{GI}=($ stem length + plant width + plant perpendicular width)/3]. Number of nodes below the first open flower was determined for marigold, primula, petunia, osteospermum, and verbena. Branch number was also recorded for all species, with the exception of stock and primula. Inflorescence size was measured for stock from the lower- to upper-most floret. Plant growth parameters, including stem length, plant widths, node number, branch number, and/ or inflorescence size, were measured at flowering for marigold, primula, osteospermum, and verbena; at marketable for calibrachoa, regal geranium, lobelia, phlox, and petunia; and $38 \mathrm{~d}$ after transplant for stock. Shoots of six plants per species per replication were excised at the growing media surface and dried in an oven at $70{ }^{\circ} \mathrm{C}$ for at least $4 \mathrm{~d}$. After drying, shoots were weighed to determine shoot dry weight (SDW).

EXPERIMENTAL DESIGN AND STATISTICAL ANALYSIS. The experiment was a complete randomized block design, with two replications and blocked by treatment (growing environment). Each replication had eight experimental units (single plant in a container) per species, which were randomized within each block. Replications were pooled based on consistent trends of treatment response. Means of treatments were compared by $t$ test using SAS (version 9.4; SAS Institute, Cary, NC) PROC TTEST at $P \leq 0.05$.

\section{Results and discussion}

ENVIRONMENTAL CONDITIONS OF HIGH TUNNEL AND OUTDOOR PRODUCTION. As expected, average air and media temperatures were consistently lower outdoors, compared with in the high tunnel (Table 1). Additionally, minimum recorded temperature was 2.4 and $-4.2{ }^{\circ} \mathrm{C}$ in the high tunnel and outdoors, respectively. It is apparent that the high tunnel was able to buffer some of the extreme night temperatures, especially early in production. Outdoor air temperatures fell below freezing on five nights in April, whereas high tunnel temperatures remained above $2{ }^{\circ} \mathrm{C}$. However, ventilation may have been limiting later in high tunnel production as a temperature extreme of $53.7^{\circ} \mathrm{C}$ occurred in June in the high tunnel, whereas the maximum outdoor air temperature was only $33.3{ }^{\circ} \mathrm{C}$. This could be due to the width of the high tunnel used, as it has been reported that passive high tunnel ventilation may not be adequate for high tunnels wider than $6 \mathrm{~m}$ ( $\approx 20 \mathrm{ft}$ ) when outdoors air temperatures exceed $30{ }^{\circ} \mathrm{C}$ (Wells and Loy, 1993). This also may have been caused by technical errors with the automatic motorized crank system and controls. The extreme temperature was likely temporary as no heat stress was visually observed. Media temperatures were consistently higher than air temperatures and displayed less fluctuation. High media temperatures were likely due to the black containers, shuttle trays, and landscape fabric below all plants. The landscape fabric in the high tunnel and outdoor plot was often warm or even hot to touch, hence heating the root-zone via conduction. MDT fluctuated more outdoors than in the high tunnel, apparent by the consistently larger sDs (Table 1). Plants that were given a 1 -week acclimation period in the high tunnel were exposed to a higher MDT in April.

Average DLI was consistently reduced by $\approx 27 \%$ in the high tunnel compared with outdoors. Single-layer polyethylene allows for $87 \%$ transmission of photosynthetically active radiation (400 to $700 \mathrm{~nm}$ ) (Bartok et al., 2001); thus, reduced transmission through the plastic covering and shading from the high tunnel structure likely caused the observed decrease in DLI. DLI outdoors was also reduced when rowcover was used to cover the crop in the late afternoon and morning. However, the rowcover provided $\approx 85 \%$ light transmittance, so effects on DLI were likely minor. Although light levels were reduced in the high tunnel compared with outdoors, high tunnels still allow for significantly increased DLI compared with greenhouses. For example, DLI in the high tunnel has been reported as 9.3 to $22.3 \mathrm{~mol} \cdot \mathrm{m}^{-2} \cdot \mathrm{d}^{-1}$ higher than in the greenhouse in April through June (Currey et al., 2014; Gerovac et al., 2015). 
Table 1. Mean daily light integral (DLI) and mean, minimum (min), and maximum (max) media and air temperature for each growing environment (GE), each month following transplant of annual bedding plants. Plants were transplanted on 13 Apr. 2015 and then grown in a high tunnel (HT), in a high tunnel for a 1-week acclimation period then outdoors (HT/O), or outdoors $(\mathrm{O})$.

\begin{tabular}{|c|c|c|c|c|c|c|c|c|}
\hline \multirow[b]{2}{*}{ Month } & \multirow[b]{2}{*}{ GE } & \multirow[b]{2}{*}{$\mathrm{DLI}\left[\right.$ mean $\left.\pm \mathrm{SD}\left(\mathrm{mol} \cdot \mathrm{m}^{-2} \cdot \mathrm{d}^{-1}\right)\right]$} & \multicolumn{3}{|c|}{ Media temp $\left({ }^{\circ} \mathbf{C}\right)^{z}$} & \multicolumn{3}{|c|}{ Air temp $\left({ }^{\circ} \mathbf{C}\right)$} \\
\hline & & & Mean \pm SD & Min & $\overline{\text { Max }}$ & Mean \pm SD & Min & Max \\
\hline \multirow[t]{2}{*}{ April ${ }^{y}$} & HT & $27.7 \pm 11.7$ & $16.4 \pm 3.9$ & 4.5 & 37.1 & $13.7 \pm 4.5$ & 2.4 & 32.6 \\
\hline & $\mathrm{O}$ & $39.2 \pm 17.0$ & $12.2 \pm 4.6$ & 1.8 & 32.5 & $11.0 \pm 5.3$ & -4.2 & 26.6 \\
\hline \multirow[t]{2}{*}{ May } & $\mathrm{HT}$ & $30.7 \pm 9.1$ & $22.8 \pm 5.3$ & 7.9 & 41.9 & $20.7 \pm 7.1$ & 2.8 & 37.8 \\
\hline & $\mathrm{O}$ & $43.4 \pm 13.2$ & $20.3 \pm 6.6$ & 3.1 & 44.8 & $19.0 \pm 8.2$ & 0.2 & 32.0 \\
\hline
\end{tabular}

${ }^{2}\left(1.8 \times{ }^{\circ} \mathrm{C}\right)+32={ }^{\circ} \mathrm{F}$.

yata for 13-30 Apr.

${ }^{x}$ Data for $1-15$ June.

EFFECTS OF HIGH TUNNEL VERSUS OUTDOOR PRODUCTION ON RATE OF PLANT DEVELOPMENT. After a few nights below freezing in April, all marigold plants growing outdoors had symptoms of freezing injury and died. Marigold was therefore excluded from further analysis. All species developed more rapidly in the high tunnel than outdoors (Table 2). Plant development is directly related to MDT (Blanchard and Runkle, 2011; Vaid and Runkle, 2013). Therefore, the overall reduced air and substrate temperatures, by 2.3 and $1.5^{\circ} \mathrm{C}$, respectively, in outdoor production likely caused the delay in flowering and marketability. When grown outdoors compared with in the high tunnel, primula, calibrachoa, and verbena were delayed by only 4,6 , and $7 \mathrm{~d}$, respectively; lobelia, phlox, and petunia experienced intermediate delays of 9,9 , and $11 \mathrm{~d}$, respectively; and regal geranium was delayed by $26 \mathrm{~d}$. Similarly, Currey et al. (2014) reported delays of 3 to $13 \mathrm{~d}$ for cold-tolerant and cold-intermediate annual bedding plants grown in a high tunnel compared with in a greenhouse, with a decrease in MDT of 3.6 to $7.5^{\circ} \mathrm{C}$. Likewise, delays of 2 to $17 \mathrm{~d}$ were reported for dianthus, petunia, and snapdragon transplanted into a hightunnel on week 14 , compared with into a greenhouse, with a decrease in MDT of 1.4 to $6.6^{\circ} \mathrm{C}$ (Gerovac et al., 2015). Given the delay in development of high tunnel production compared with greenhouse, additional delays should be expected when comparing outdoor production to greenhouse production.

EFFECTS OF HIGH TUNNEL VERSUS OUTDOOR PRODUCTION ON PLANT GROWTH AND MORPHOLOGY. Growth is a function of net photosynthesis, which is affected by both temperature and $P P F$ (van Iersel, 2003). Although mean outdoor temperatures were lower than in the high tunnel, light levels were higher; thus increasing the photothermal ratio, or the ratio of radiant energy to thermal energy (moles per square meter per degreeday). Photothermal ratio has been proposed to balance the ratio of plant growth to plant development, and increased photothermal ratio has been reported to increase overall crop quality (Blanchard et al., 201 la; Liu and Heins, 2002). For example, increased photothermal ratio resulted in increased biomass accumulation, stem diameter, and inflorescence diameter, and decreased plant height of 'Freedom' poinsettia (Euphorbia pucherrima), all conferring increased plant quality (Liu and Heins, 2002). Photothermal ratio has also been reported to be positively correlated with flower bud number and negatively correlated with plant height of petunia (Blanchard et al., 201la). As expected, with increased photothermal ratio in outdoor production, reduced stem length and GI were observed for lobelia, osteospermum, stock, and verbena grown outdoors, compared with in the high tunnel (Table 2). Growing environment had no effect on stem length for all other species; however, petunia had an increased GI when grown outdoors compared with in the high tunnel. Reduced stem length of plants grown outdoors is probably also a result of thigmomorphogenesis, such as by wind and precipitation (Downs and Krizek, 1997; Latimer, 1998; Mitchell, 1996). Mechanical stress has been reported to reduce plant height by
$20 \%$ to $50 \%$ (Latimer, 1998). These reductions are similar to results of PGR application, and thus could limit the need for chemical height control in outdoor production (Latimer, 1998).

SDW of calibrachoa, regal geranium, petunia, and phlox was higher for plants grown outdoors compared with in the high tunnel, which could be a result of increased photothermal ratio, increased DLI, or increased time to accumulate biomass (Faust et al., 2005; Liu and Heins, 2002; Moccaldi and Runkle, 2007). Faust et al. (2005) reported increasing plant dry weight with increasing DLI from 5 to $43 \mathrm{~mol} \cdot \mathrm{m}^{-2} \cdot \mathrm{d}^{-1}$ for eight bedding plant species. Similar studies have also found increased SDW at flowering with decreased MDT, due to increased production time, which could describe the same trend observed in the present study, as temperatures were consistently lower outdoors than in the high tunnel (Moccaldi and Runkle, 2007; Vaid et al., 2014). Net photosynthesis has been found to be maximal at 14 to $15{ }^{\circ} \mathrm{C}$ for multiple annual bedding plant species (van Iersel, 2003). Biomass accumulation is a result of net photosynthesis and duration of photosynthate accumulation. Low air temperature and high DLI, resulting in an increased photothermal ratio, as well as increased TTF and TTM likely caused the observed increased SDW. Contrariwise, osteospermum and stock had decreased SDW when grown outdoors compared with in the high tunnel. Low outdoor temperatures may have limited photosynthetic ability or damaged the cellular photosynthetic apparatus for these crops. When grown outdoors, 
Table 2. Mean stem length, growth index [(stem length + plant width + plant perpendicular width)/3], node number (below first open flower), branch number, and shoot dry weight (SDW) measured at flowering for marigold, primula, osteospermum, and verbena, at marketable (when plants had at least one open flower and filled out the container) for calibrachoa, regal geranium, lobelia, phlox, and petunia, and $38 \mathrm{~d}$ after transplant for stock; and time to flower (TTF) and time to marketable (TTM) of 10 annual bedding plant crops transplanted on 13 Apr. 2015 and then grown in a high tunnel (HT), in a high tunnel for a l-week acclimation period then outdoors (HT/O), or outdoors $(\mathrm{O})$.

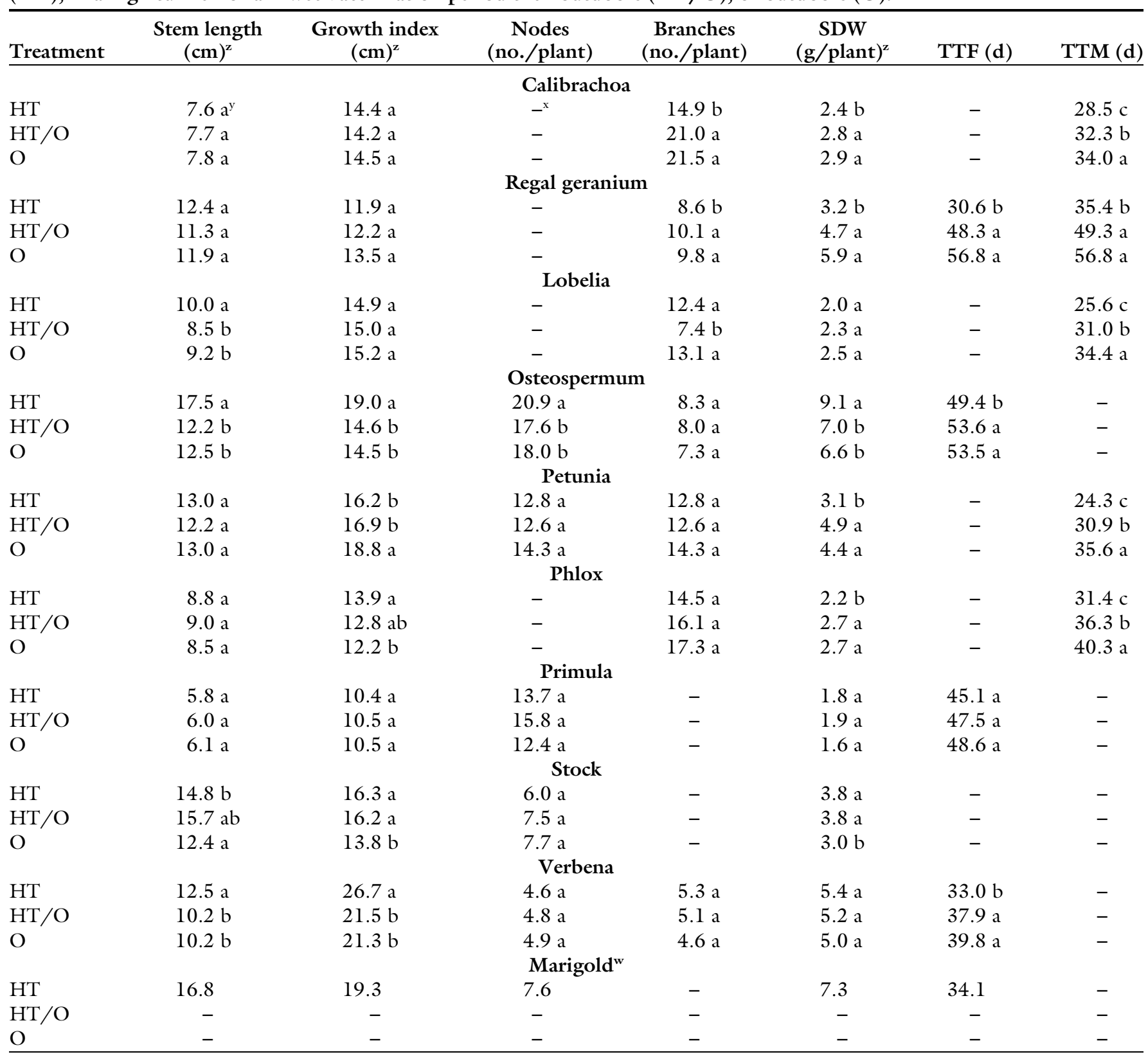

${ }^{\mathrm{z}} 1 \mathrm{~cm}=0.3937$ inch, $1 \mathrm{~g}=0.0353 \mathrm{oz}$.

${ }^{y}$ Means with the same letter within a column per species are not different based on a $t$ test at $P \leq 0.05$.

'Data not collected.

"All marigolds grown outdoors died due to low temperature in early April.

osteospermum and stock exhibited a decrease in overall size, in terms of stem length, GI, and SDW. Node number of osteospermum and inflorescence size of stock was also reduced for plants grown outside compared with those in the high tunnel (data not shown). Node number was similar for all other species grown outdoors or in the high tunnel. Similarly, previous studies have reported that DLI and temperature did not consistently affect node number (Moccaldi and Runkle, 2007; Vaid and Runkle, 2013). Branch number at flowering increased for calibrachoa and regal geranium grown outdoors compared with in the high tunnel. All other species had similar branch number regardless of growing environment. Branching is generally positively correlated with DLI and inversely related to MDT (Faust et al., 2005; Kaczperski et al., 1991; Vaid et al., 2014). This probably balanced the effects of high tunnel and outdoor production, as MDT was lower, but DLI was higher outdoors compared with in the high tunnel.

EFFECTS OF AN ACCLIMATION PERIOD BEFORE OUTDOOR PRODUCTION. When plants were given 
a l-week acclimation period in the high tunnel before outdoor production, all species, with the exception of regal geranium, were delayed by 1 week or less ( 2 to $7 \mathrm{~d}$ ) compared with when grown in the high tunnel. This may highlight the importance of an acclimation period early in production to reduce developmental delay for some crops. An acclimation period in the high tunnel before outdoor production significantly hastened development in calibrachoa, lobelia, petunia, and phlox. However, the 1week acclimation period did not significantly affect TTF or TTM of regal geranium, osteospermum, primula, and verbena compared with those grown outdoors (Table 2). Similarly, Gerovac et al. (2015) reported that an acclimation period of 1 to 2 weeks in the greenhouse at $21^{\circ} \mathrm{C}$ before transplant into the high tunnel reduced TTF for some crops, such as petunia and snapdragon, but had no effect on TTF of dianthus. The 1 -week acclimation period had little to no effect on growth and morphology of all species.

\section{Conclusions}

Overall, plant development was delayed for all species grown outdoors compared with in the high tunnel. These delays varied by species from only $4 \mathrm{~d}$ (primula) to $26 \mathrm{~d}$ (regal geranium). All species, other than regal geranium, acclimated in the high tunnel for 1 week before being grown outdoors were delayed by less than 1 week compared with when grown entirely in the high tunnel. Later planting dates or implementation of an acclimation period could potentially prevent or reduce developmental delays, as early spring cold temperatures could be avoided or reduced (Gerovac et al., 2015).

Stem length at flowering was reduced or similar for all plants grown outdoors compared with in the high tunnel, whereas SDW and branch number of most species grown outdoors was greater than or equal to those grown in the high tunnel. Given that compact and wellbranched plants with high SDW are considered high-quality annual bedding plants, most crops produced outdoors were of equal or greater quality to those in the high tunnel (Vaid et al., 2014). This increased quality is probably a result of the increased photothermal ratio,
DLI, and air movement observed outdoors compared with inside the high tunnel (Blanchard et al., 201 la; Downs and Krizek, 1997; Faust et al., 2005; Liu and Heins, 2002). Outdoor production may therefore be suitable for production of some cold-tolerant and cold-intermediate bedding crops, and could reduce the need for PGR applications; but growers must plan for some delay and be aware of the risk of crop loss due to extreme weather in early spring.

\section{Literature cited}

Adams, S.R, P. Hadley, and S. Pearson. 1998. The effects of temperature, photoperiod, and photosynthetic photon flux on the time to flowering of petunia 'Express Blush Pink'. J. Amer. Soc. Hort. Sci. 123:577-580.

Bartok, J.W., Jr., W.J. Roberts, E. FabianWheeler, and J. Simpkins. 2001. Energy conservation for commercial greenhouses. Natural Resource Agr. Eng. Serv. (NRAES), Ithaca, NY.

Blanchard, M.G. and E.S. Runkle. 2011. Quantifying the thermal flowering rates of eighteen species of annual bedding plants. Scientia Hort. 128:30-37.

Blanchard, M.G., E.S. Runkle, and P.R. Fisher. 2011a. Modeling plant morphology and development of petunia in response to temperature and photosynthetic daily light integral. Scientia Hort. 129:313-320.

Blanchard, M.G., E.S. Runkle, and J.M. Frantz. 2011b. Energy-efficient greenhouse production of Petunia and Tagetes by manipulation of temperature and photosynthetic daily light integral. Acta Hort. 893:857-864.

Crum, D. 2008. Talking shop: Maximizing space. Greenhouse Grower 27(1):52-56.

Currey, C.J., R.G. Lopez, and N.S. Mattson. 2014. Finishing bedding plants: A comparison of an unheated high tunnel versus a heated greenhouse in two geographic locations. HortTechnology 24:527-534.

Downs, R.J. and D.T. Krizek. 1997. Air movement, p. 87-104. In: R.W. Langhans and T.W. Tibbitts (eds.). Plant growth chamber handbook. North Central Regional Res. Publ., No. 340, Iowa State Agr. Home Econ. Expt. Sta. Spec. Rpt. No. 99.

Faust, J.E., V. Holcombe, N.C. Rajapakse, and D.R. Layne. 2005. The effect of daily light integral on bedding plant growth and flowering. HortScience 40:645649.

Gerovac, J.R., R.G. Lopez, and N.S. Mattson. 2015. High tunnel versus cli- mate-controlled greenhouse: Transplant time and production environment impact growth and morphology of cold-tolerant bedding plants. HortScience 50:830-838.

Heins, R.D., B. Liu, and E.S. Runkle. 2000. Regulation of crop growth and development based on environmental factors. Acta Hort. 511:15-24.

Kaczperski, M.P., W.H. Carlson, and M.G. Karlsson. 1991. Growth and development of Petunia $\times$ bybrida as a function of temperature and irradiance. J. Amer. Soc. Hort. Sci. 116:232-237.

Lamont, W. 2009. Overview of the use of high tunnels worldwide. HortTechnology 19:25-29.

Latimer, J.G. 1998. Mechanical conditioning to control height. HortTechnology 8:529-534.

Liu, B. and R.D. Heins. 2002. Photothermal ratio effects plant quality in 'Freedom' poinsettia. J. Amer. Soc. Hort. Sci. 127:20-26.

Lopez, R.G. and E.S. Runkle. 2014. Growing your crops above their base temperature. Greenhouse Grower 32(8):53-55.

Mitchell, C.A. 1996. Recent advances in plant response to mechanical stress: Theory and application. HortScience 31:31-35.

Moccaldi, L.A. and E.S. Runkle. 2007. Modeling the effects of temperature and photosynthetic daily light integral on growth and flowering of Salvia splendens and Tagetes patula. J. Amer. Soc. Hort. Sci. 132:283-288.

Oh, W., E.S. Runkle, and R.M. Warner. 2010. Timing and duration of supplemental lighting during the seedling stage influence quality and flowering in petunia and pansy. HortScience 45:1332-1337.

Vaid, T.M. and E.S. Runkle. 2013. Developing flowering rate models in response to mean temperature for common annual ornamental crops. Scientia Hort. 161:15-23.

Vaid, T.M., E.S. Runkle, and J.M. Frantz. 2014. Mean daily temperature regulates plant quality attributes of annual ornamental plants. HortScience 49:574-580.

van Iersel, M.W. 2003. Short-term temperature change affects the carbon exchange characteristics and growth of four bedding plant species. J. Amer. Soc. Hort. Sci. 128:100-106.

Wells, O. and J. Loy. 1993. Rowcovers and high tunnels enhance crop production in the northeastern United States. HortTechnology 3:92-95.

Wien, H.C. 2009. Floral crop production in high tunnels. HortTechnology 19:56-60. 